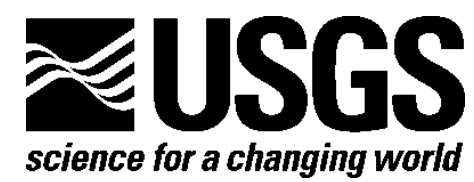

\title{
Conodont Color Alteration (CAl) as an Aid to Structural Interpretation in the Black Pine Mountains, Idaho
}

By J. Fred Smith, Jr. and Bruce R. Wardlaw

Open-File Report 2012-1100

U.S. Department of the Interior

U.S. Geological Survey 


\section{U.S. Department of the Interior \\ KEN SALAZAR, Secretary}

\section{U.S. Geological Survey \\ Marcia K. McNutt, Director}

U.S. Geological Survey, Reston, Virginia: 2012

For product and ordering information:

World Wide Web: http://www.usgs.gov/pubprod

Telephone: 1-888-ASK-USGS

For more information on the USGS-the Federal source for science about the Earth,

its natural and living resources, natural hazards, and the environment:

World Wide Web: http://www.usgs.gov

Telephone: 1-888-ASK-USGS

Suggested citation:

Smith, J.F., Jr., and Wardlaw, B.R., 2012, Conodont color alteration (CAI) as an aid to structural interpretation in the Black Pine Mountains, Idaho: U.S. Geological Survey Open-File Report 2012-1100, 5 p., available only at http://pubs.usgs.gov/of/2012/1100.

Any use of trade, product, or firm names is for descriptive purposes only and does not imply endorsement by the U.S. Government.

Although this report is in the public domain, permission must be secured from the individual copyright owners to reproduce any copyrighted material contained within this report. 


\section{Contents}

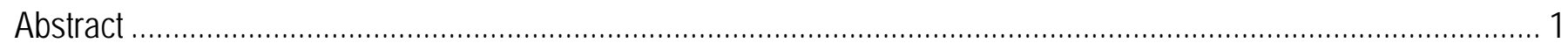

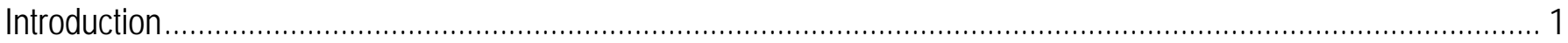

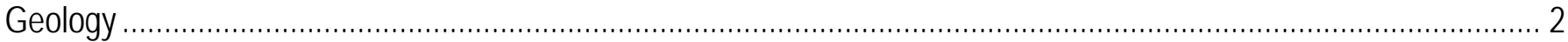

Conodont Color Alteration Indices in the Black Pine Mountains ...................................................................... 4

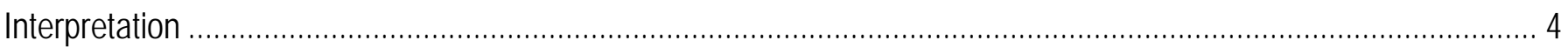

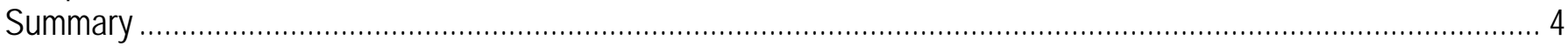

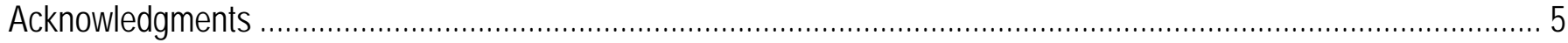

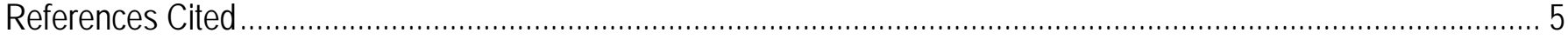

\section{Figures}

1. Index map showing location of Black Pine Mountains (Strevell 15-minute quadrangle),

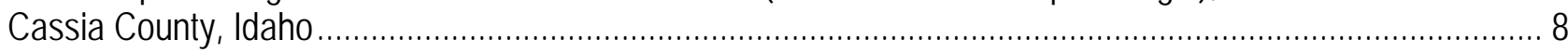

2. A, Generalized geologic map of Paleozoic rocks in the Black Pine Mountains (Strevell 15-minute quadrangle) modified from Smith (1982); B, Map of outcrop area of Paleozoic rocks in the Black Pine Mountains showing conodont localities 9

\section{Table}

1. Conodonts reported from samples submitted, Strevell 15-minute quadrangle, Cassia County, Idaho In a separate file 


\section{Conversion Factors}

Inch to SI

\begin{tabular}{lll}
\hline \multicolumn{1}{c}{ Multiply } & By & To obtain \\
\hline foot (ft) & Length & \\
mile (mi) & 0.3048 & meter (m) \\
mile, nautical (nmi) & 1.609 & kilometer (km) \\
yard (yd) & 1.852 & kilometer (km) \\
\hline SI to Inch/Pound & 0.9144 & meter (m) \\
\hline \multicolumn{1}{c}{ Multiply } & & \\
\hline & By & To obtain \\
\hline meter (m) & Length & \\
kilometer (km) & 3.281 & foot (ft) \\
kilometer (km) & 0.6214 & mile (mi) \\
meter (m) & 0.5400 & mile, nautical (nmi) \\
\hline
\end{tabular}

Temperature in degrees Celsius $\left({ }^{\circ} \mathrm{C}\right)$ may be converted to degrees Fahrenheit $\left({ }^{\circ} \mathrm{F}\right)$ as follows:

${ }^{\circ} \mathrm{F}=\left(1.8 \times{ }^{\circ} \mathrm{C}\right)+32$ 


\title{
Conodont Color Alteration (CAI) as an Aid to Structural Interpretation in the Black Pine Mountains, Idaho
}

\author{
By J. Fred Smith, Jr. ${ }^{1}$ and Bruce R. Wardlaw
}

\begin{abstract}
The Black Pine Mountains, southeastern Cassia County, Idaho, consist of southern and northern blocks separated by a northeast-trending, high-angle fault. Differences in conodont color alteration values distinguish the two blocks. The southern block has significantly higher organic maturation levels than the northern block and is interpreted to have been thrust northeastward adjacent to the northern block.
\end{abstract}

\section{Introduction}

The Black Pine Mountains (Strevell 15-minute quadrangle), Cassia County, Idaho (fig. 1), are transected by a northeast-trending fault that separates the range into two blocks. Values of CAI (color alteration index) of conodonts from Mississippian to Permian rocks are very different on opposite sides of this fault. This difference in values is useful to understanding the relative movement on the fault.

Conodont CAI values have been shown to be useful indicators of organic metamorphism in Ordovician through Triassic rocks (Epstein and others, 1977). Harris and others (1978) used CAI values for indicating thermal maturity in assessing hydrocarbon potential in Paleozoic rocks of the Appalachian basin. Harris and others (1980) applied the same technique to the Great Basin for assessing thermal maturity. CAI analysis of collections from relatively small areas may also aid in structural interpretations by indicating contiguous structural blocks with similar thermal histories and by indicating other, perhaps adjacent, blocks with markedly different thermal histories. The use of CAI values in structural interpretation in eastern Tennessee has been demonstrated by Epstein and others (1977, fig. 15). This report on the Black Pine Mountains demonstrates the usefulness of this technique in a small area in the Great Basin-Rocky Mountains region.

Color or CAI values are expressed as numbers from 1 to 8 (Epstein and others, 1977; Rejebian and others, 1987). Values recorded from the Black Pine Mountains range from 3.0 to 6.5, which equate to temperatures ranging from $110^{\circ} \mathrm{C}$ to $500^{\circ} \mathrm{C}$. A low- to high-temperature range is given for each value, as Epstein and others (1977) determined that color alteration in conodonts is both time and temperature dependent.

\footnotetext{
${ }^{1}$ Deceased.
} 


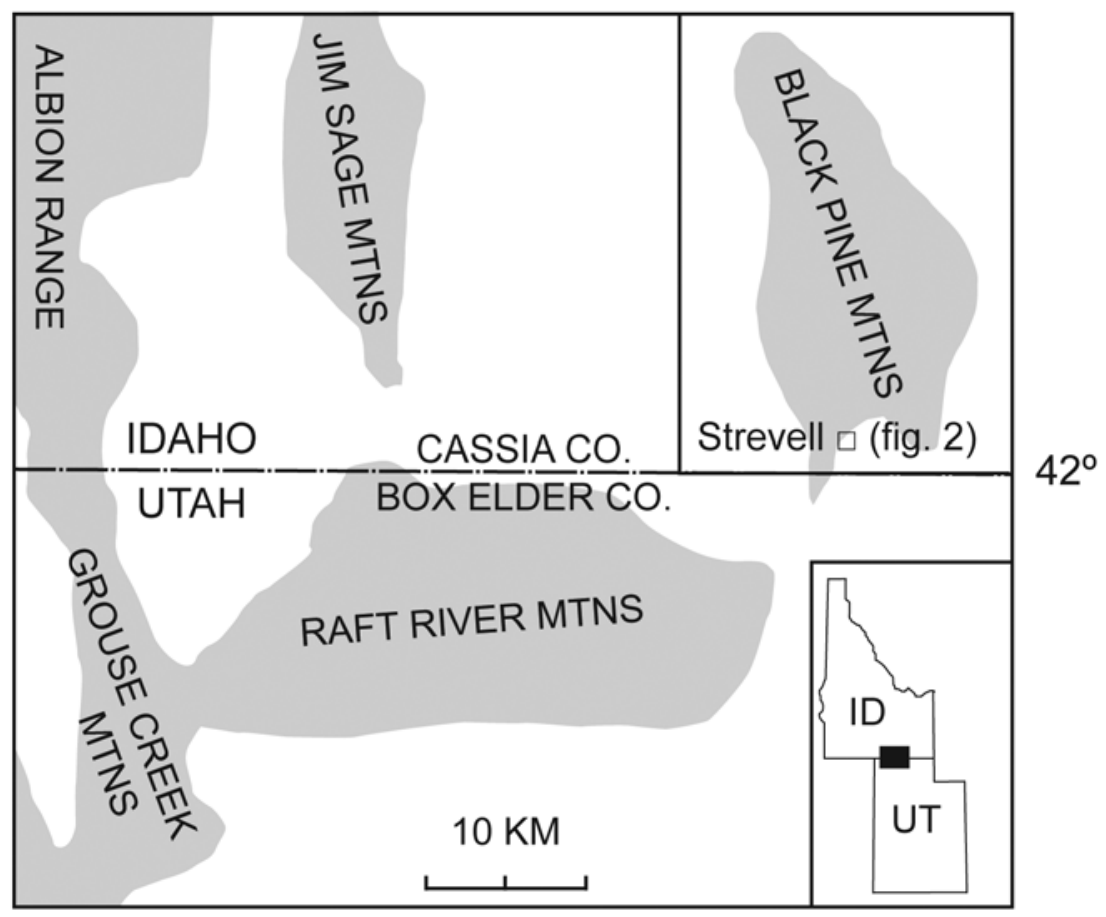

Figure 1. Index map showing location of Black Pine Mountains (Strevell 15-minute quadrangle), Cassia County, Idaho.

The trace amount of organic matter encased in the apatite skeleton of individual conodont elements gradually changes color from amber to black as carbon is fixed within the temperature range of $50^{\circ} \mathrm{C}$ to $300^{\circ} \mathrm{C}$. At higher temperatures $\left(400^{\circ} \mathrm{C}-500^{\circ} \mathrm{C}\right)$, the carbon is gradually burned off and the apatite skeleton gradually decomposes, resulting in color changes from black to gray to white to crystalclear before the conodont element is completely destroyed. Conodonts, therefore, can indicate minimum and maximum temperatures attained by their host rocks through a wide thermal range $\left(50^{\circ} \mathrm{C}-500^{\circ} \mathrm{C}\right)$. These temperatures relate chiefly to depth and duration of burial and to geothermal gradients.

\section{Geology}

Paleozoic rocks in the Black Pine Mountains range in age from Middle Devonian to Middle Permian (fig. 2). They consist of siltstone, limestone, dolostone, quartzite, all gradations between limestone and sandstone and siltstone, and chert. The mountain range is separated into two structural blocks by a northeast-trending fault near West Dry Canyon (fig. 2). Rock units from which conodont collections were made south of this fault include the Upper Mississippian and Lower Pennsylvanian Manning Canyon Shale and the Lower Pennsylvanian (Bashkirian) to Lower Permian (Artinskian) Oquirrh Formation of which four informal members are recognized. Four units from which conodonts were collected north of the fault and in the northeastern part of the Strevell quadrangle range from Upper Pennsylvanian (Gzhelian) to Middle Permian (Roadian). South of the range-transecting fault, all contacts between mapped units are low-angle faults. North of the range-transecting fault, one contact appears to be a fault and the others appear to be conformable (fig. 2A). 

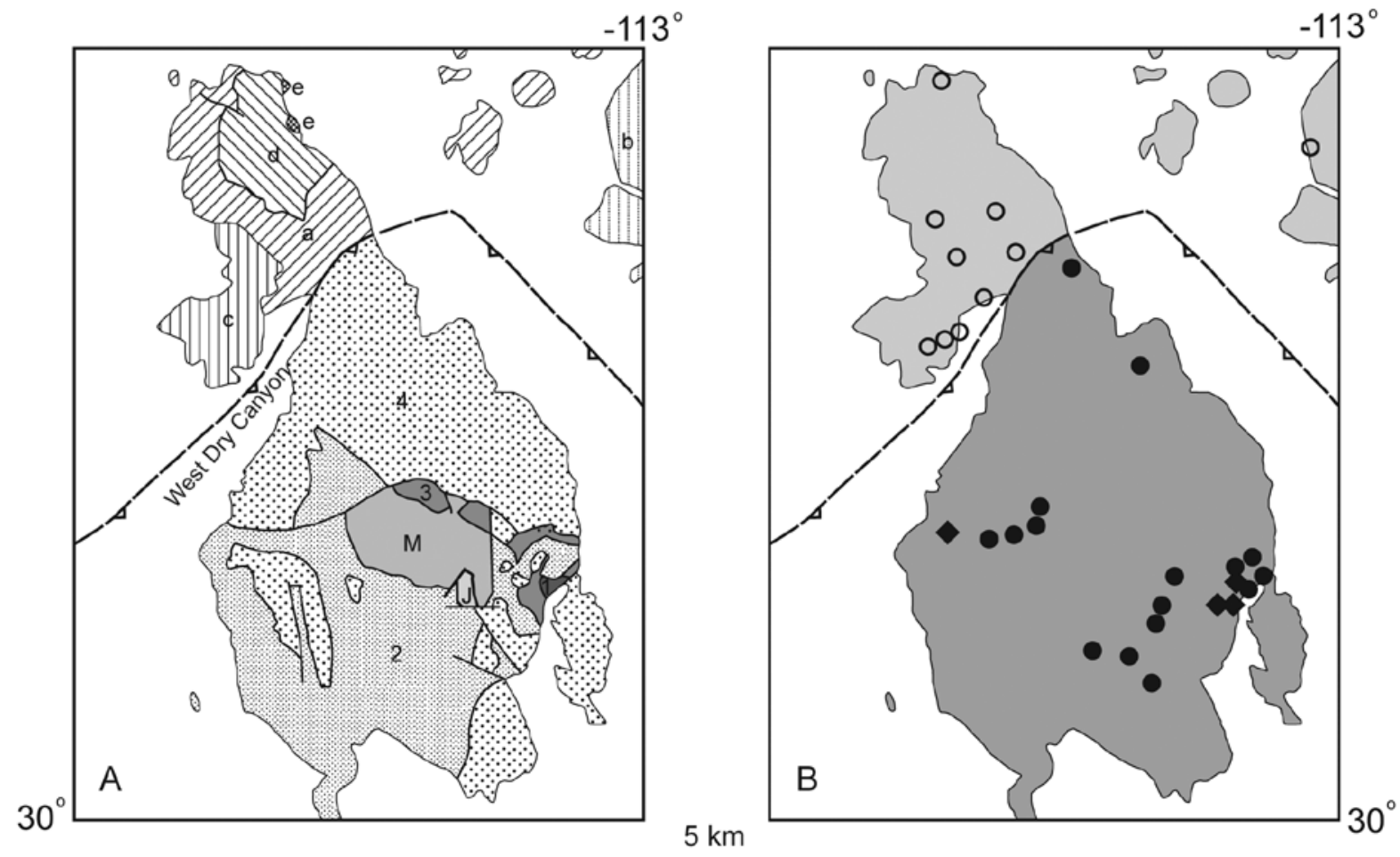

NORTH BLOCK

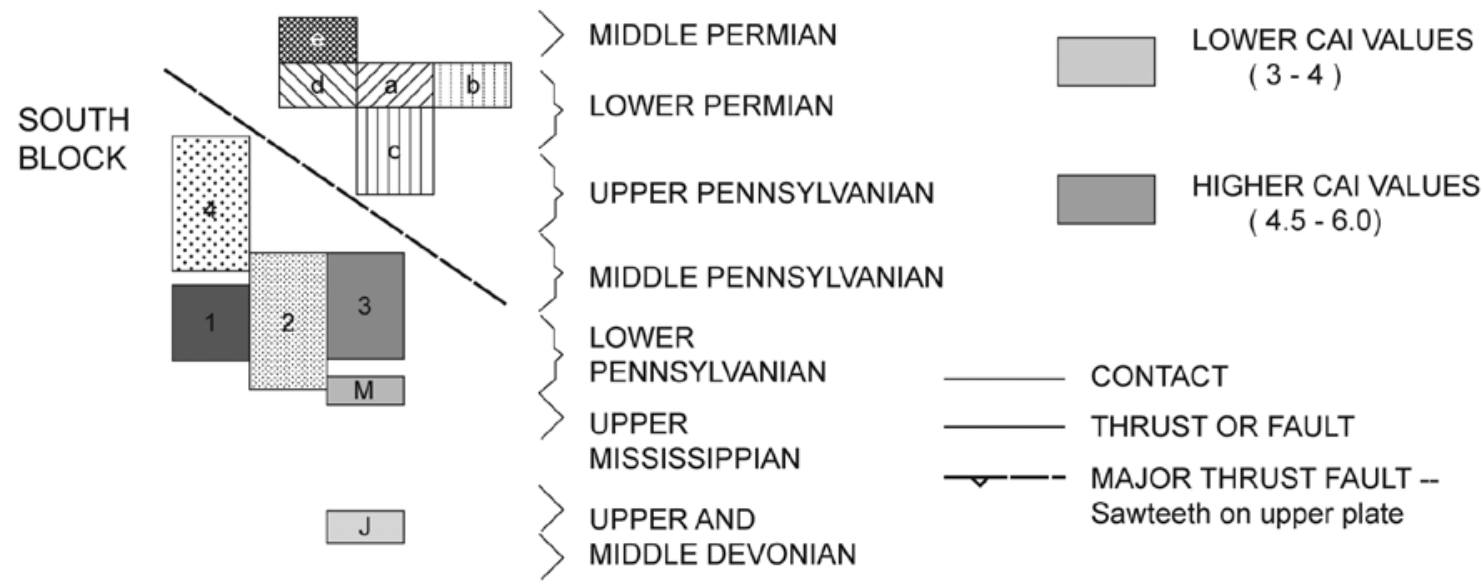

Figure 2. A, Generalized geologic map of Paleozoic rocks in the Black Pine Mountains (Strevell 15-minute quadrangle) modified from Smith (1982); north block map units: a, limestone, silty limestone, dolostone, siltstone and sandstone with chert; $b$, chert, siltstone, and limestone; c, calcareous siltstone, calcareous sandstone, and silty limestone; d, dark-gray limestone; e, silicified limestone, limestone, and limestone breccias. South block map units: $\mathrm{J}$, Jefferson Formation; M, Manning Canyon Shale; and informal members of the Oquirrh Formation: 1, limestone, sandstone, and quartzite; 2 , limestone; 3 , limestone and dolostone; 4 , sandstone and siltstone. B, Map of outcrop area of Paleozoic rocks in Black Pine Mountains showing conodont localities; open circles indicate CAl values of 3.0 to 4.0, solid circles indicate CAl values of 4.5 to 5.5 , and solid diamonds indicate CAI values of 5.5 to 6.5 . 


\section{Conodont Color Alteration Indices in the Black Pine Mountains}

CAI values of two conodont collections south of the fault transecting the Black Pine Mountains (fig. 2B) have a range from $4.5\left(240^{\circ} \mathrm{C}-400^{\circ} \mathrm{C}\right)$ to $6.5\left(450^{\circ} \mathrm{C}-500^{\circ} \mathrm{C}\right)$; most of the collections have a value of $5.0\left(300^{\circ} \mathrm{C}\right.$ to $\left.400^{\circ} \mathrm{C}\right)$. CAI values of 10 conodont collections north of the range-transecting fault have a range from $3.0\left(110^{\circ} \mathrm{C}-200^{\circ} \mathrm{C}\right)$ to $4.0\left(190^{\circ} \mathrm{C}-300^{\circ} \mathrm{C}\right)$ with all but one value being 4.0 (table 1). There is no overlap in CAI values north and south of the fault.

\section{Interpretation}

The difference in CAI values and inferred temperatures on the two sides of the range-transecting fault is interpreted to indicate distinct thermal histories for the two structural blocks. It is inferred that the sediments of the blocks were deposited at some distance from each other, underwent different general geologic and thermal histories, and were subsequently juxtaposed structurally. Rocks of the northern block are younger than and partly equivalent to those of the southern block (fig. 2). Differences in lithology and CAI values in correlative (Gzhelian to Artinskian) units of the two blocks indicate somewhat different depositional environments and thermal histories. The correlative units are unit 4 in the southern block and unit c in the northern block (fig. 2A).

The youngest beds of the northern block are younger than those of the southern block (Roadian versus Artinskian; early Middle Permian versus late Early Permian); these beds, however, do not exceed a thickness of 2,300 meters (m), and it seems doubtful that the differences in CAI values resulted simply from differences in overburden. Furthermore, CAI values south of the fault are similar through a stratigraphic thickness of about 5,500 m, and those north of the fault are similar through a stratigraphic thickness of about $2,800 \mathrm{~m}$. This indicates that the elevated temperatures probably were pervasive through at least these rock thicknesses.

Overturned folds in some units of the southern block indicate that at least part of the deformation was related to generally eastward-directed movements (Smith, 1983). The southern block is interpreted to have moved northeastward relative to the northern block and to have formed an upper plate that cut across the northern block along the northeast-trending, essentially vertical (strike-slip) part of the fault. It also rode up and over the northern block along the northwest-trending part of the fault inferred to be covered by Quaternary deposits east of the Black Pine Mountains (fig. 2). The differences in CAI values of conodonts in the two blocks suggest that the southern block originated in an area of higher heat flow than that of the northern block. This higher heat flow is of uncertain origin, although it may possibly have been related to development of the metamorphic complexes of the Raft River Mountains and Albion Range (fig. 1). Temperatures attained by rocks in the northern block may have been related to some part of the same complexes but farther removed from the heat source than the southern block.

CAI values can be used to assess organic maturation in the Black Pine Mountains. These values suggest that post-mature or high-temperature methane stage of petroleum generation was reached (for example, see Hood and others, 1975, p. 993-994; Epstein and others, 1977, p. 22-25; Milner and others, 1977, p. 107-108) and that occurrence of liquid hydrocarbons is unlikely. Although the possibility that there is a lower structural plate consisting of rocks of lower organic maturation cannot be disproved, it also seems unlikely.

\section{Summary}

Conodont CAI values provide data that can be used in structural interpretations, although relations of indices may not always be as clearly drawn as they seem to be in the Black Pine Mountains. 
Differences in CAI values in the two principal structural blocks of these mountains suggest that these blocks originated in different thermal regimes before being juxtaposed by faulting. The southern block is interpreted to have been thrust adjacent to the northern block. Geologic data from the Black Pine Mountains are not adequate to demonstrate whether or not the lower part of the northern block is autochthonous.

\section{Acknowledgments}

Anita G. Harris and John E. Repetski wrote initial conodont reports on a few samples. This paper was prepared in 1981 but was set aside upon the death of the senior author. Recent inventory of the USGS collections at the National Museum of Natural History identified matrix collections that were collected for fusulinids and etched for conodonts in 1979 by Wardlaw. These collections made up about half of those reported here. The discovery of the sampled matrix collections led to the discovery of the last version of the manuscript, which is updated here. As the senior author originally pointed out, this paper makes for a good case study in the use of conodont derived thermal maturity in structural interpretations.

\section{References Cited}

Epstein, A.G., Epstein, J.B., and Harris, L.D., 1977, Conodont color alteration; An index to organic metamorphism: U.S. Geological Survey Professional Paper 995, 27 p.

Harris, A.G., Harris, L.D., and Epstein, J.B., 1978, Oil and gas data from Paleozoic rocks in the Appalachian basin; Maps for assessing hydrocarbon potential and thermal maturity (conodont color alteration isograds and overburden isopachs): U.S. Geological Survey Miscellaneous Investigations Series Map I-917-E, scale 1:2,500,000.

Harris, A.G., Wardlaw, B.R., Rust, C.C., and Merrill, G.K., 1980, Maps for assessing thermal maturity (conodont color alteration index maps) in Ordovician through Triassic rocks in Nevada and Utah and adjacent parts of Idaho and California: U.S. Geological Survey Miscellaneous Investigations Series Map I-1249, scale 1:2,500,000.

Hood, A., Gutjahr, C.C.M., and Heacock, R.L., 1975, Organic metamorphism and the generation of petroleum: American Association of Petroleum Geologists Bulletin, v. 59, no. 6, p. 986-996.

Milner, C.W.D., Rogers, M.A., and Evans, C.R., 1977, Petroleum transformations in reservoirs: Journal of Geochemical Exploration, v. 7, no. 2, p. 101-153.

Rejebian, V.A., Harris, A.G., and Huebner, J.S., 1987, Conodont color and textural alteration; An index to regional metamorphism, contact metamorphism, and hydrothermal alteration: Geological Society of America Bulletin, v. 99, no. 4, p. 471-479.

Smith, J.F., Jr., 1982, Geologic map of the Strevell 15-minute quadrangle, Cassia County, Idaho: U.S. Geological Survey Miscellaneous Investigations Series Map I-1403, scale 1:62,500.

Smith, J.F., Jr., 1983, Paleozoic rocks in the Black Pine Mountains, Cassia County, Idaho: U.S. Geological Survey Bulletin 1536, 36 p. 